\section{Enhancing Tribal Energy Security and Clean Energy}

\section{What Is START?}

The Strategic Technical Assistance Response Team (START) Program is part of the U.S. Department of Energy (DOE) Office of Indian Energy Policy and Programs (Office of Indian Energy) effort to assist in the development of tribal renewable energy projects. Through START, Tribes in the 48 contiguous states and Alaska can apply for and are selected to receive technical assistance from DOE to move projects closer to implementation.

The START Program seeks to spur clean energy project development by providing Tribes with tools and resources needed to foster energy self-sufficiency, sustainability, and economic competitiveness. START assists tribal leadership with project development and financing and helps tribal communities strategically plan their energy future.

\section{What Does START Do?}

Through the START program, the DOE Office of Indian Energy works directly with tribal communities to evaluate project financial and technical feasibility, provide ongoing training to community members, and help implement a variety of clean energy projects, including energy storage infrastructure, renewable energy deployment, and energy efficiency.

"The START Program helps Native American and Alaska Native communities enhance their energy security and create job opportunities in the clean energy economy. Building upon the achievements and lessons learned from the program's first round, our new technical assistance awards for clean energy projects will help more tribal communities across the country deploy sustainable energy resources and increase local generation capacity."

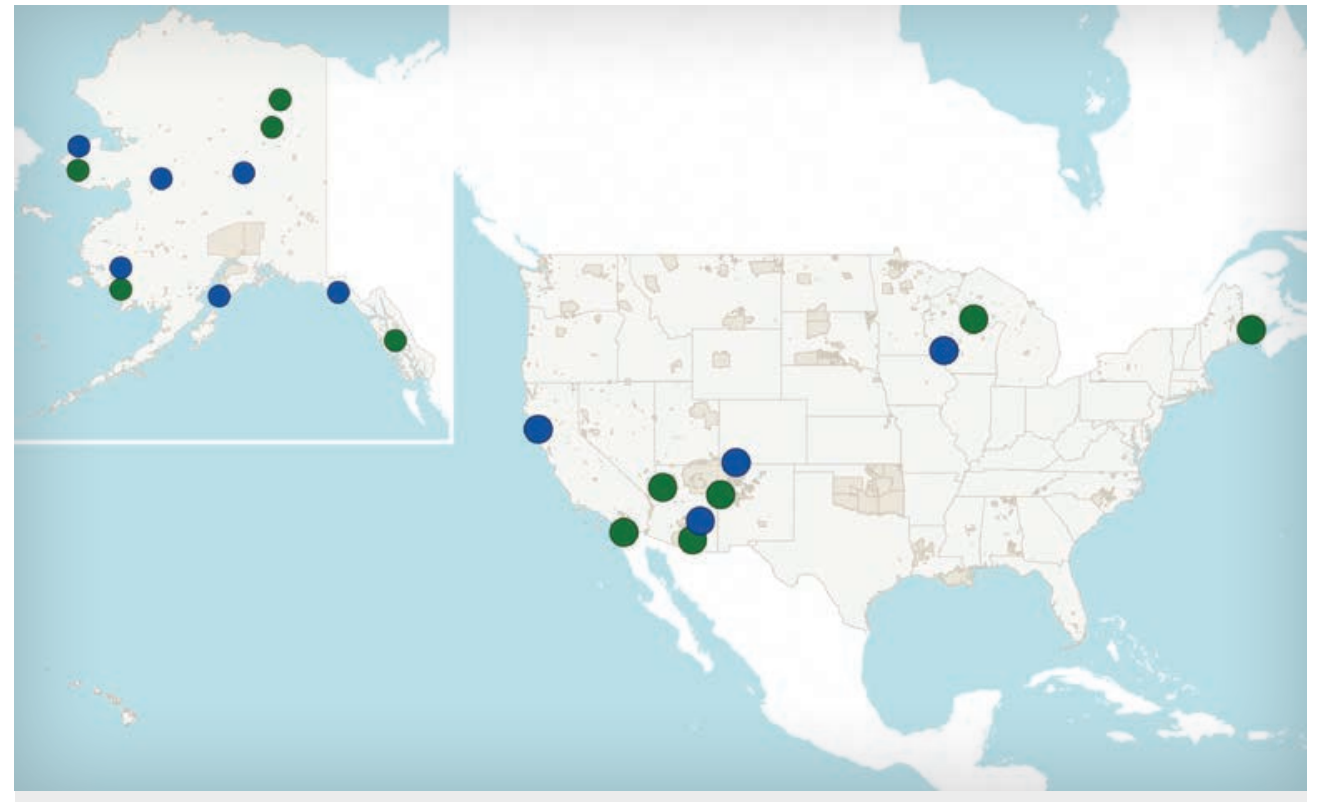

2012 START Program Project Sites

Arctic Village Council

Campo Band of the Kumeyaay Nation

Hualapai Tribe

Native Village of Kwinhagak

Native Village of Teller

Organized Village of Kake

Pascua Yaqui Tribe

Passamaquoddy Tribes of Indian Township and Pleasant Point

Pueblo of Zuni

Venetie Village Council
Forest County Potawatomi Community

\section{START Program Project Sites}

Chugachmiut Regional Corporation Ho-Chunk Nation

Native Village of Kongiganak Native Village of Koyukuk Native Village of Minto Native Village of Shishmaref Pinoleville Pomo Nation San Carlos Apache Tribe Southern Ute Indian Tribe Yakutat T'lingit Tribe

\section{START 2012}

In 2012, the DOE Office of Indian Energy launched the START Program and delivered customized on-site technical expertise to support six Tribes in the 48 contiguous states in pursuing the development and financing of specific renewable energy projects. Additionally, in partnership with the Denali Commission, the DOE Office of Indian Energy supported community-based energy planning and staff training for five Alaska Native villages.

\section{START 2013}

The START 2013 effort will continue to provide assistance to further advance Native American and Alaska Native communities' efforts to increase local energy generation capacity, improve energy efficiency, and create local entrepreneurial and job opportunities.

START 2013 projects were selected through a competitive application process. Between January 30 and March 15, 2013, 42 Indian Tribes in the 48 contiguous states and Alaska submitted applications to receive on-the-ground technical support through START. Technical assistance activities are scheduled for summer and fall 2013 and will focus on the following efforts. 


\section{Renewable Energy Project Development Assistance}

The START team will help four Tribes in the 48 contiguous states, as well as an Alaska Native Regional Corporation, move community- and commercial-scale projects closer to implementation. This includes working directly with the tribal project team and tribal legal/finance specialists who address or will address late-stage project development decisions, negotiations, and agreements.

\section{Alaska Native Community Energy Planning and Projects}

In Alaska, the START team, led by the DOE Office of Indian Energy in partnership with the Denali Commission, the DOE Office of Energy Efficiency and Renewable Energy, and the National Renewable Energy Laboratory, will provide technical assistance with community-based energy planning, energy awareness and training programs, and clean energy deployment and financing opportunities. Each village is also eligible for up to $\$ 250,000$ in financial assistance to deploy a renewable energy or energy efficiency project, supported by DOE's Tribal Energy grant program.

\section{More Information}

Learn more about the START projects at energy.gov/indianenergy/resources/ start-program.

\section{START Projects}

2012

\begin{tabular}{|c|c|c|c|}
\hline Tribe & Location & Project & \\
\hline Arctic Village Council & Alaska & & $\begin{array}{l}\text { Community Energy Planning and } \\
\text { Clean Energy Projects }\end{array}$ \\
\hline $\begin{array}{l}\text { Campo Band of the } \\
\text { Kumeyaay Nation }\end{array}$ & California & & Commercial-Scale Wind Farm \\
\hline $\begin{array}{l}\text { Forest County Potawatomi } \\
\text { Community }\end{array}$ & Wisconsin & & Community-Scale Biomass \\
\hline Hualapai Tribe & Arizona & & Solar PV Micro-Grid System \\
\hline $\begin{array}{l}\text { Native Village of } \\
\text { Kwinhagak }\end{array}$ & Alaska & & $\begin{array}{l}\text { Community Energy Planning and } \\
\text { Clean Energy Projects }\end{array}$ \\
\hline Native Village of Teller & Alaska & & $\begin{array}{l}\text { Community Energy Planning and } \\
\text { Clean Energy Projects }\end{array}$ \\
\hline Organized Village of Kake & Alaska & & $\begin{array}{l}\text { Community Energy Planning and } \\
\text { Clean Energy Projects }\end{array}$ \\
\hline Pascua Yaqui Tribe & Arizona & & Facility-Scale Solar PV System \\
\hline $\begin{array}{l}\text { Passamaquoddy Tribes } \\
\text { of Indian Township and } \\
\text { Pleasant Point }\end{array}$ & Maine & & Commercial-Scale Wind Farm \\
\hline Pueblo of Zuni & $\begin{array}{l}\text { New } \\
\text { Mexico }\end{array}$ & 成 & $\begin{array}{l}\text { Community-Scale Solar } \\
\text { PV System }\end{array}$ \\
\hline Venetie Village Council & Alaska & & $\begin{array}{l}\text { Community Energy Planning and } \\
\text { Clean Energy Projects }\end{array}$ \\
\hline
\end{tabular}

2013

\begin{tabular}{|c|c|c|c|}
\hline Tribe & Location & Project & \\
\hline $\begin{array}{l}\text { Chugachmiut } \\
\text { Regional } \\
\text { Corporation }\end{array}$ & Alaska & & Community-Scale Biomass \\
\hline Ho-Chunk Nation & Wisconsin & & Community-Scale Biomass \\
\hline $\begin{array}{l}\text { Native Village } \\
\text { of Kongiganak }\end{array}$ & Alaska & & $\begin{array}{l}\text { Community Energy Planning and } \\
\text { Clean Energy Projects }\end{array}$ \\
\hline $\begin{array}{l}\text { Native Village } \\
\text { of Koyukuk }\end{array}$ & Alaska & & $\begin{array}{l}\text { Community Energy Planning and } \\
\text { Clean Energy Projects }\end{array}$ \\
\hline $\begin{array}{l}\text { Native Village } \\
\text { of Minto }\end{array}$ & Alaska & & $\begin{array}{l}\text { Community Energy Planning and } \\
\text { Clean Energy Projects }\end{array}$ \\
\hline $\begin{array}{l}\text { Native Village } \\
\text { of Shishmaref }\end{array}$ & Alaska & & $\begin{array}{l}\text { Community Energy Planning and } \\
\text { Clean Energy Projects }\end{array}$ \\
\hline $\begin{array}{l}\text { Pinoleville } \\
\text { Pomo Nation }\end{array}$ & California & & Community-Scale Solar \\
\hline $\begin{array}{l}\text { San Carlos } \\
\text { Apache Tribe }\end{array}$ & Arizona & & $\begin{array}{l}\text { Facility-Scale Solar } \\
\text { PV System }\end{array}$ \\
\hline $\begin{array}{l}\text { Southern Ute } \\
\text { Indian Tribe }\end{array}$ & Colorado & & $\begin{array}{l}\text { Community-Scale Solar } \\
\text { PV System }\end{array}$ \\
\hline $\begin{array}{l}\text { Yakutat } \\
\text { T'lingit Tribe }\end{array}$ & Alaska & & $\begin{array}{l}\text { Community Energy Planning and } \\
\text { Clean Energy Projects }\end{array}$ \\
\hline
\end{tabular}

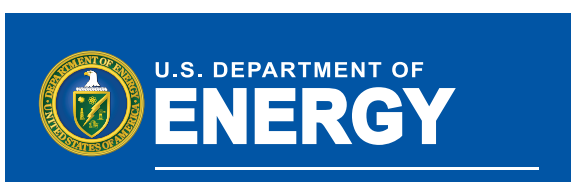

Office of

Indian Energy
Through the Energy Policy Act of 2005, the Department of Energy, through the Office of Indian Energy, is authorized to fund and implement a variety of programmatic activities that assist Tribes and Alaska Native villages and corporations with energy development, capacity building, energy infrastructure, reduction of energy costs, and electrification of Indian lands and homes. The Office also oversees tribal grants to support the evaluation, development, and deployment of energy efficiency and renewable energy projects on tribal lands that help save energy, expand the use of clean energy resources, and promote tribal economic development. energy.gov/indianenergy indianenergy@hq.doe.gov

July 2013 - DOE/IE-0026

Printed with a renewable-source ink on paper containing at least $50 \%$ wastepaper, including $10 \%$ post consumer waste. 